\title{
Review on Non-Conventional Energy Resources in India
}

\author{
Mohammad Miyan*1 and M. K. Shukla ${ }^{2}$ \\ 1.* Associate Professor and Head of Department Mathematics, Shia P. G. College, University of Lucknow-226020, (U.P.), India. \\ e-mail : miyanmohd@rediffmail.com \\ 2. Assistant Professor and Department of Mathematics, Shia P. G. College, University of Lucknow-226020, (U.P.), India.
}

\section{Publication Info}

Article history :

Received : $15^{\text {th }}$ Sept., 2018

Accepted : $16^{\text {th }}$ Nov., 2018

DOI : 10.18090/samriddhi.v10i02.2

\section{Keywords :}

Bio mass fuel, Renewable energy, Solar energy, Tidal energy, Wind energy.

*Corresponding author :

Mohammad Miyan

e-mail : miyanmohd@ rediffmail.com

\begin{abstract}
The sources of energy that are exhaustible and being made unceasingly in nature are known as nonconventional energy or renewable sources of energy. The standard sources embrace the fossil fuels i.e., coal, oil and gas, sorts of atomic energy i.e., Uranium, whereas the nonconventional sources like daylight, wind, rain, tides, and energy heat, that are renewable. Since the event and progress of grouping are closely associated with energy sources, several countries throughout the globe have engaged themselves in looking and developing non-conventional energy sources that may be terribly essential to sustain the life cycle of person. The consumption of energy is directly proportional to the progress of the grouping. With ever growing population, improvement within the living commonplace of the mankind, industrialization of developing countries, the world demand for energy is anticipated to extend considerably within the close to future. The energy crisis that began in 1973 caused oil provides to decrease and costs to rise usuriously. This crisisforced developing countries to cut back or hold over necessary development programs, so that they may purchase oil to stay their economies operational. It created the imperative necessity to seek out and develop energy sources, like different fossil fuels i.e., coal, gas, atomic energy, and renewable energy resources. Our country, Republic of India has additionally taken sure initiatives during this read. In this paper, a review based mostly study has been given concerning numerous non-conventional energy sources and their current standing and usage in India.
\end{abstract}

\section{INTRODUCTION}

$\mathrm{R}$ enewable energy resources are mostly biomass-based and are available in unlimited amount in nature since these can be renewed i.e., regenerated in natural process over relatively short period of time. Renewable energy sources are inexhaustible, i.e. they can be replaced after we use them and can produce energy again and again. These include, firewood or fuel wood obtained from forest, petro plants, plant biomass as agricultural wastes like bagasse, animal dung, solar energy, wind energy, water energy i.e., hydro-electrical, ocean wave and tidal energy, and geothermal energy etc. These can reproduce themselves in nature and can be harvested continuously through a sustained proper planning and management.

Non-renewable energy resources are available in limited amount and develop over a longer period of time. As a result of unlimited use, they are likely to be exhausted one day. These include various fossil fuels including petroleum products, coal and natural gas and nuclear energy. Nuclear energy is 
mainly obtained from the nuclear fission of the uranium and thorium. The global resources of fossil fuel and uranium and thorium are limited and will be eventually be depleted. Moreover, use of fossil fuels for energy has negative environmental consequences, such as air pollution, global warming, acid rains and oil spills. Thus, it has been become essential to minimize the use of fossil fuels and to replace them with renewable resources.

Renewable energy resources are principally biomass-based and are offered in unlimited quantity in nature since these will be revived i.e., regenerated in activity over comparatively short amount of your time. Renewable energy sources are inexhaustible, i.e. they will get replaced once we tend to use them and may turn out energy once more and once more. These embody, fuel or fuel wood obtained from forest, petro-plants, plant biomass as agricultural wastes like pulp, animal dung, alternative energy, wind energy, water energy i.e., hydro-electrical, ocean wave and recurrent event energy, and heat etc. These will reproduce themselves in nature and may be harvested unendingly through a sustained correct designing and management.

Non-renewable energy resources are offered in restricted quantity and develop over an extended amount of your time. As results of unlimited use, they're probably to be exhausted in some unspecified time in the future. These embody varied fossil fuels together with fossil fuel merchandise, coal and gas and energy. Energy is principally obtained from the fission of the metallic element and metal. The world resources of fuel and metallic element and metal area unit restricted and can be eventually be depleted. Moreover, use of fossil fuels for energy has negative environmental consequences, like pollution, heating, acid rains and oil spills. Thus, it's been become essential to reduce the employment of fossil fuels and to switch them with renewable resources.

The energy sources are classified as Conventional and Non-conventional sources and described as:

\subsection{Conventional Sources of Energy}

- The sources of energy that are in use for an extended time, e.g., coal, petroleum, gas and water power.

- They are exhausting ready except water.

- They cause pollution once used, as they emit smoke and ash.

- They are terribly high-ticket to be maintained, keep and transmitted as they're carried over long distance through transmission grid and contours.

\subsection{Non-Conventional Sources of Energy}

- The resources that are measure however within the method of development over the past few years. It includes solar, wind, tidal, biogas, and biomass, geothermal.

- They are measure inexhaustible.

- They are measure typically pollution free.

- Less overpriced because of native use and straight forward to take care of.

\section{SOLAR ENERGY}

Sun is the source of all energy on the earth. It is most abundant, inexhaustible and universal source of energy. All other sources of energy draw their strength from the sun. Solar energy can be used directly or indirectly for human welfare. The direct solar energy is the radiant energy, whereas the indirect solar energy obtained from the materials such as biomass, in which sun's radiant energy has been incorporated by the plants. On global scale, 15 days of solar energy is roughly equivalent to the energy stored in all known reserves of fossil fuels on the earth. The continuous input of the energy from the sun is 1, 67,000 times 
greater than the current consumption. As such, now many countries are in effort to harness the solar energy for domestic, commercial or industrial purposes. Solar energy can be used for direct heating. Alternatively, the heat can be converted into the electricity- the thermal electric generation. Photovoltaic cells-the solar cells or solar batteries convert direct solar energy into electricity.

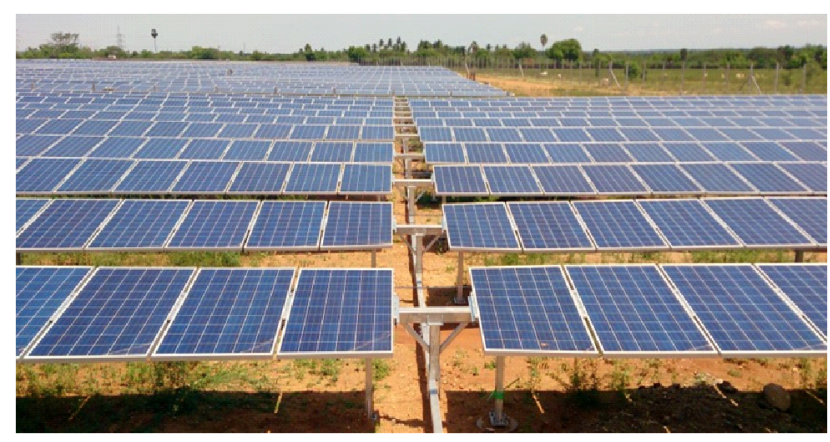

Fig.1: Solar Energy Plant

Solar power in India may be a big developing industry. The country's solar power in capability reached $26 \mathrm{GW}$ as of 30 September 2018. India distended its solar-generation capability eight times from 2,650 MW on 26 May 2014 to over 20 $\mathrm{GW}$ as on 31 January 2018. The $20 \mathrm{GW}$ capabilities were at the start targeted for 2022 however the Govt. achieved the target four years prior to schedule. The country updated its $3 \mathrm{GW}$ of solar capability in 2015-2016, 5 GW in 20162017 and over $10 \mathrm{GW}$ in 2017-2018, with the typical current value of solar electricity dropping to $18 \%$ below the current value of its coal-fired counterpart.

In Jan-2015, the Indian government expanded its solar plans, targeting US\$100 billion in investment and $100 \mathrm{GW}$ of solar capacity including $40 \mathrm{GW}$ from rooftop solar by 2022 . India's initiative of $100 \mathrm{GW}$ of solar energy by 2022 is an excellent target, since the world's installed solar power capacity in 2017 is expected to be $303 \mathrm{GW}$. The improvements in solar thermal storage power technology in the latest years has made this task achievable as cheaper solar power and does not depend on cost and pollution based coal/gas/nuclear power generation for ensuring stable grid operation.

In addition to the large scale grid based solar PV initiative, India is developing the off-grid solar power for the local energy needs. The solar products have increasingly helped to meet the rural needs; by the end of the year 2015 just smaller than one million solar lanterns, were sold in the country to reducing need for kerosene. In that year, 118,700 solar home light systems were installed and 46,655 solar street light installations were provided with respect to the national program; more than 1.4 million solar cookers were given to peoples in India.

In Jan-2016, the India PM and French President laid the foundation stone for the headquarters of ISA (International Solar Alliance) in Gwal Pahari, Gurgaon. The ISA will focus to promote and develop the solar energy and solar products for the countries lying wholly or partially between the Tropic of Capricorn and the Tropic of Cancer. The alliance of more than 120 countries was declared at the Paris COP21 climate summit. The one hope of the ISA is that the wider deployment will reduce the production and development costs that would facilitate the increased deployment of the solar technologies to some poor and the remote regions.

The report published by the Institute for Energy Economics and Financial Analysis (IEEFA) observed that the India installed $10 \mathrm{GW}$ of solar in 2017 that is the double of its own record in 2016. But, India's "Scheme for Development of Solar Parks" has proven successful to attract the foreign capital for the construction of world's biggest ultra mega solar parks. 


\section{WIND ENERGY}

The potential for the wind farms in India was assessed in 2011 to be more than 2,000 GW by Prof. J. Hossain of TERI University, New Delhi. This was subsequently re-validated by Lawrence Berkley National Laboratory, US (LBNL) in an independent study in 2012. As a result, MNRE constitute a committee to reassess the potential and through the National Institute of Wind Energy (NIWE) has declared a revised analysis of potential wind resource in India from 49,130 MW to 302,000 MW analyzed at $100 \mathrm{~m}$ hub height. The wind turbines are now being placed at even 120 $\mathrm{m}$ hub height and wind resource at the higher hub heights of around $120 \mathrm{~m}$ that exists is possibly even more.

In the year 2015, the MNRE set the target of Wind Power generation capacity by the year 2022 up to 60,000 MW. North east and East regions have no grid connected the wind power plant as of December 2017.

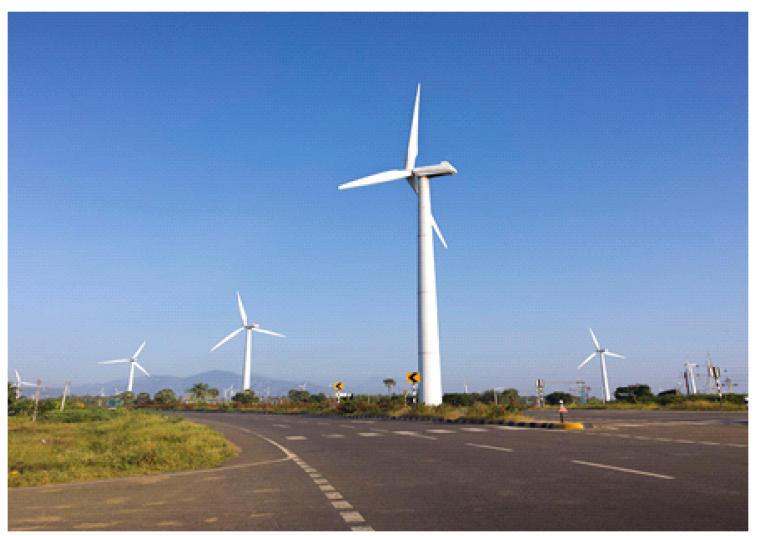

Fig.2: Wind Power Plant

No offshore wind energy facility is underneath implementation as of December 2017. However, an Offshore Wind Policy was proclaimed in 2015 and presently weather stations and LIDARs are being discovered by NIWE at some locations. The primary offshore wind energy facility is planned close to Dhanushkodi in Madras.
Wind power accounts for nearly $10 \%$ of India's total put in power generation capability and generated 52.67 TWh within the year 2017-18, that is sort of $3 \%$ of total electricity generation. The capability usage issue is sort of $16 \%$ within the year 2017-18 i.e., $19.62 \%$ in 2016-17 and 14 July in 2015-16. The $70 \%$ of wind power is throughout the 5 months length from May to September coinciding with Southwest monsoon length. In India, the solar energy is complementary to alternative energy because it is generated principally throughout the non monsoon amount in daytime.

\section{TIDAL ENERGY}

Tidal power or periodic event energy may be a sort of hydropower that converts the energy obtained from tides into helpful sorts of power, chiefly electricity.

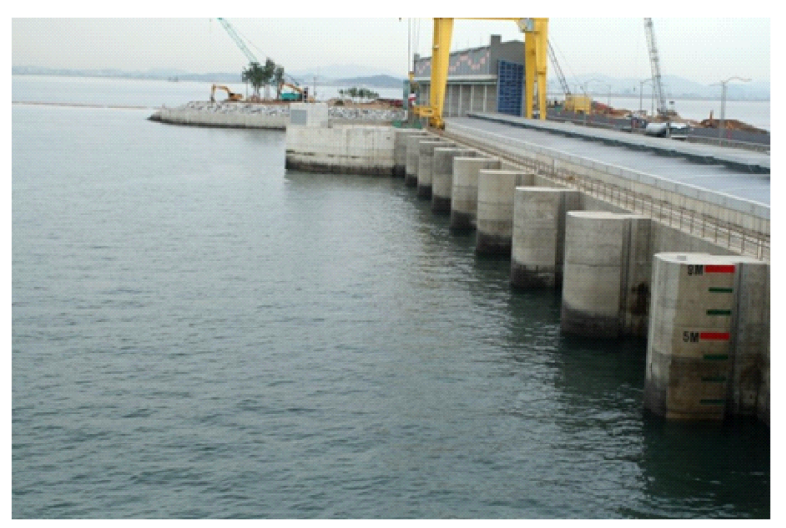

Fig.3: Sihwa Lake Tidal Power Station, located in Gyeonggi Province, South Korea, is the world's largest tidal power installation, with a total power output capacity of $254 \mathrm{MW}$

Although not however wide used, periodic event energy has potential for future electricity generation. Tides are a lot of certain than the wind and also the sun. Among sources of renewable energy, periodic event energy has historically suffered from comparatively high price and restricted handiness of web sites with sufficiently high periodic event ranges or flow velocities, so constricting its total handiness. However, several 
recent technological developments and enhancements, each in style (e.g. dynamic periodic event power, periodic event lagoons) and rotary engine technology (e.g. new axial turbines, cross flow turbines), indicate that the overall handiness of periodic event power could also be a lot of on top of antecedently assumed, which economic and environmental prices could also be brought all the way down to competitive levels.

Historically, tide mills are used each in Europe and on the coast of North America. The incoming water was contained in giant storage ponds, and because the tide went out, it turned water wheels that used the mechanical power it created to mill grain. The earliest occurrences start the center Ages, or maybe from Roman times. The process of mistreatment falling water and spinning turbines to form electricity was introduced within the U.S. and Europe within the nineteenth century.

The world's 1st large-scale periodic event station was the Rance periodic event power plant in France that became operational in 1966. It had been the most important periodic event power plant in terms of output till Sihwa Lake periodic event power plant opened in South Korea in August 2011. The Sihwa station uses ocean wall defense barriers complete with ten turbines generating $254 \mathrm{MW}$.

\section{OCEAN THERMAL ENERGY}

Ocean thermal energy conversion (OTEC) uses the temperature distinction between cooler deep and hotter shallow or surface seawaters to run an engine and turn out helpful work, sometimes within the variety of electricity. OTEC will operate with an awfully high capability issue then will operate in base load mode.

Among ocean energy sources, OTEC is one amongst the incessantly offered renewable energy resources that would contribute to base-load power offer. The resource potential for OTEC is taken into account to be abundant larger than for different ocean energy forms [World Energy Council, 2000]. Up to $88,000 \mathrm{TWh} / \mathrm{yr}$ of power can be generated from OTEC while not moving the ocean's thermal structure.

Systems are also either closed-cycle or opencycle. Closed-cycle OTEC uses operating fluids that are usually thought of as refrigerants like ammonia or R-134a. These fluids have low boiling points, and square measure so appropriate for powering the system's generator to come up with electricity. The foremost normally used heat cycle for OTEC so far is that the Rankine cycle, employing an unaggressive rotary engine. Opencycle engines use vapor from the sea water itself because the operating fluid.

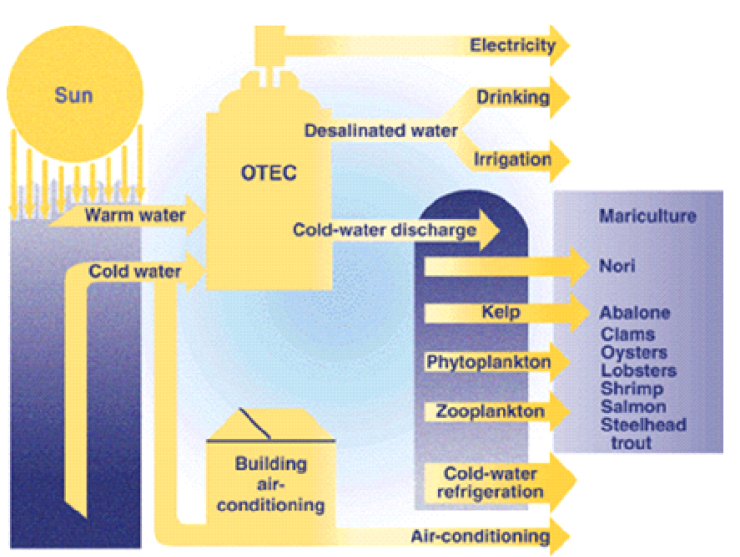

Fig.4: OTEC diagram and applications

OTEC can even offer quantities of cold water as a by-product. This will be used for air conditioning and refrigeration and also the nutrient-rich deep ocean water can feed biological technologies. Another by-product is $\mathrm{H}_{2} \mathrm{O}$ distilled from the ocean.

\section{WAVE ENERGY}

India contains a long outline of $7517 \mathrm{~km}$ marked on by various estuaries and gulfs that makes it engaging for the event of marine energy comes. India's wave power potential is around 40$60 \mathrm{GW}$. But, compared to the developments in alternative renewable energy technologies, ocean 
energy technologies like wave and periodic event are in their emerging stages of development in India. Wave power depends upon the peak of the wave and its amount. Primary estimates of wave energy potential on Indian coast is around 5-15 $\mathrm{MW} / \mathrm{m}$, therefore the theoretical calculable potential comes bent on be around 40-60 GW. A study by IIT Madras and Credit Rating data Services of Indian Ltd (CRISIL) have shown that western coast has higher alternative energy potential compared to eastern coast. They need known potential locations for wave power development on the West Coast of India in geographical region, Goa, Karnataka and Kerala. Kanyakumari set at the southern tip of Indian land has the best power thanks to the results of refraction and powerful winds. With presently obtainable technologies, quantity of power that may be generated victimization wave energy is way but the theoretical calculable potential. Capacity Utilization issue for wave energy in India is within the variation of $15-20 \%$.

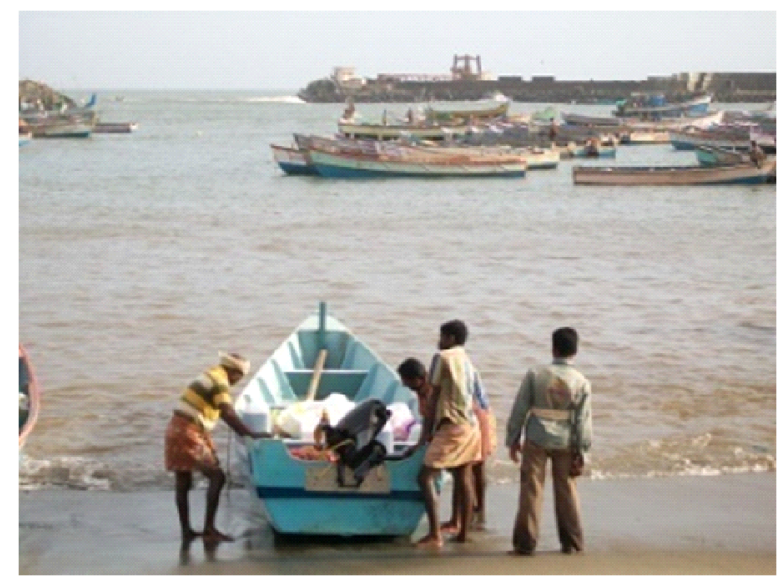

Fig.5: Vizhinjam Wave Power Plant

\section{GEOTHERMAL ENERGY}

Geothermal energy is that the natural heat of the world. Earth's interior heat originated from its fiery consolidation of mud and gas over four billion years past. It's frequently regenerated by the decay of radioactive components that occur all told rocks. From the surface down through the crust, the traditional gradient - the rise of temperature with the rise of depth - within the layer is $17{ }^{\circ} \mathrm{C}-30^{\circ} \mathrm{C}$ per kilometer of depth $\left(50^{\circ} \mathrm{F}-\right.$ $87^{\circ} \mathrm{F}$ per mile).

Below the crust is that the mantle, fabricated from extremely viscous, molten rocks with temperatures between $650{ }^{\circ} \mathrm{C}-1250{ }^{\circ} \mathrm{C}$ $\left(1200{ }^{\circ} \mathrm{F}-2280{ }^{\circ} \mathrm{F}\right)$. At the Earth's core, that consists of a liquid outer core and a solid inner core, temperatures vary from $4000{ }^{\circ} \mathrm{C}-7000{ }^{\circ} \mathrm{C}$ $\left(7200{ }^{\circ} \mathrm{F}-12600{ }^{\circ} \mathrm{F}\right)$.

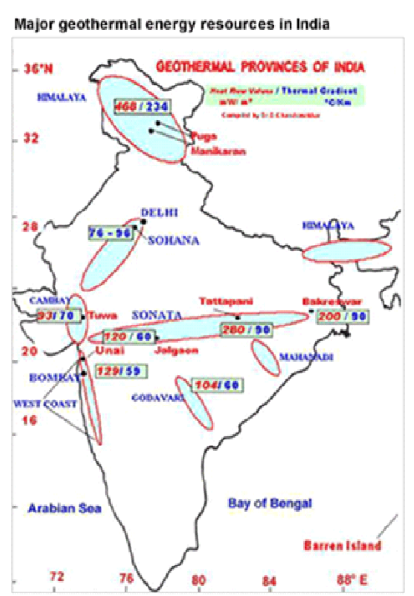

Fig.6: Places of geothermal energy in India

\section{ENERGY FROM BIOMASS}

India is perfect surroundings for Biomass production given its tropical location and ample sunshine and rains. The countries immense agricultural potential provides large agro-residues which might be accustomed meet energy desires, each in heat and power applications.

\begin{tabular}{|l|l|}
\hline \multicolumn{2}{|c|}{ Table-1: Various Types of Agro field / Industrial Residues } \\
\hline Type of Agro residues & Quantity(Million Tonnes / annum) \\
\hline Straws of various pulses and cereals & 225.50 \\
\hline Bagasse & 31.00 \\
\hline Rice Husk & 10.00 \\
\hline Groundnut shell & 11.10 \\
\hline Stalks & 2.00 \\
\hline Various Oil Stalks & 4.50 \\
\hline Others & 65.90 \\
\hline Total & 350.00 \\
\hline
\end{tabular}


According to IREDA "Biomass is capable of supplementing the coal to the tune of regarding 260 million tones", saving of regarding Rs. 250 billion, every year. It's calculable that the potential for biomass energy in India includes 16,000 MW from biomass energy and an additional 3,500 MW from pulp cogeneration. Biomass materials that may be used for power generation embrace pulp, rice husk, straw, cotton stalk, coconut shells, soya husk, de-oiled cakes, low waste, jute wastes, and groundnut shells and saw mud.

\section{CONCLUSION}

Developing renewable energy will facilitate India increase its energy security, cut back adverse impacts on the native atmosphere, lower its carbon intensity, contribute to a lot of balanced regional development, and understand its aspirations for leadership in high-technology industries. In line with a report, India is that the third most favored destination globally, for investments within the renewable energy sector. The report conjointly says that the country is going to be a serious supply of recent entrants into the world, once the North American country and China. The Indian renewable energy market has become progressively dynamic in recent years as results of robust natural resources, larger accommodation to international investments and a spread of state incentives. Solar and wind energy are going to be the key areas to witness overseas investments and acquisitions within the close to future.

With all the enticing characteristics and potential, India presents a major market chance for renewable energy corporations worldwide. In India, there's nice scope for the event of nonconventional and renewable energy sectors. India is that the solely country that has associate exclusive Ministry for brand spanking new and Non-Conventional Energy Sources. India possesses the most important redistributed solar power program, the second largest biogas and improved stove programs, and also the fifth largest wind generation program within the world. However, Indian Government and completely different NGOs have unfold their hands to market the event of non-conventional energy sectors in India by implementing different policies and techniques. These embody innovation and basic analysis in non-conventional/ renewable energy technologies, establishing courses on nonconventional/ renewable energy in teaching, partitioning the barriers to development and business readying of biomass, hydropower, solar and wind technologies, promoting the event and manufacture of tiny wind electrical generators, and enhancing the regulatory/ tariff regime so as to main stream non-conventional and renewable energy sources within the national power grid.

However, these corporations can want external steering and help on many strategic and operational aspects before they're in an exceedingly position to effectively faucet into this chance.

\section{REFERENCES}

[1] Chynoweth, D. P. and Isaacson, (1987); H. R., Anaerobic digestion of biomass New York, N Y: Elsevier Applied Sciences Publishers Ltd. EIA, Energy Information Agency, "Solar Energy," Washington, D.C., October, 1998.

[2] Das, S. and Sikdar, S. (2016); A Review on the Nonconventional Energy Sources in Indian Perspective, International Research Journal of Engineering and Technology (IRJET), Vol. 3(2), pp. 403-409.

[3] Davies, M. P. (1998); Non-Conventional Energy Development in India, A report of studies conducted through a Fulbright grant to India, pp. 04-32.

[4] Foster, R. E. (1994); Photovoltaic Energy for Agriculture, Energy Conservation and Management Division; Energy, Minerals and Natural Resources Department, Santa Fe, New Mexico, pp. 6.

[5] India Energy Portal, (2018); Geothermal. (Online) Available: http://www.indiaenergyportal.org/ subthemes_link.php?text=geothermalandthemeid=13

[6] Johnson, G. L. (2001); Wind Energy Systems, (Electronic Edition), Manhattan, KS. 
[7] Sharma, S. (2014); Non Conventional Energy's Overview Sources of India, International Journal of Engineering Research and General Science Vol. 2(4), pp. 12-20.

[8] Lalwani, M. and Singh, M. (2010); Conventional and renewable energy scenario of India: present and future, Canadian Journal on Electrical and Electronics Engineering, Vol. 1(6), pp. 122-140.

[9] Lok Sabha Secretariat (2012); Availability of Identified Non-Conventional Resources of Energy - Their Potential VIS-À-VIS Utilization $\left(29^{\text {th }}\right.$ Report of Standing Committee on Energy 2011-12). Available: http://re.indiaenvironmentportal.org.in/ files/file/Availability\%20of\%20Identified\%20Nonconventional\%20Resources\%20of\%20Energy.pdf

[10] Mahajan, S. (2013); Renewable energy resources available in India as an alternative for conventional energy resources, International Journal of Advanced Biotechnology and Research, Vol. 4(1), pp. 175-179.

[11] Ravindran, M. and Abraham, R. (2002); The Indian 1 MW demonstration OTEC plant and the development activities, OCEANS '02 MTS/IEEE Conference, Vol.3, pp. 1622-1628. doi: 10.1109/ OCEANS.2002.1191877.

[12] Sadawarte, Y. A., Rajashree T. H., Pathak, P. and Tripathi, S. (2016); Non Conventional Sources of Energy, International Research Journal of
Engineering and Technology (IRJET), Vol. 3(2), pp. 01-11.

[13] Singh, J. and Gu, S. (2010); Biomass conversion to energy in India-A critique, Renewable and Sustainable Energy Reviews, Vol. 14, pp. 13671378, doi: 10.1016/j.rser.2010.01.013.

[14] Singal S. K. et al. (2005); Development of nonconventional energy sources, 9th NCB International Seminar on Cement and Building Materials, New Delhi, Nov. 8-11, 2005.

[15] Wikipedia, (2018); Solar power in India. (Online) Available: https://en.wikipedia.org/wiki/Solar_ power_in_India (1 November 2018)

[16] Wikipedia, (2018); Wind power in India. (Online) Available: https://en.wikipedia.org/wiki/Wind_ power_in_India (31 October 2018).

[17] Wikipedia, (2018); Tidal power. (Online) Available: https://en.wikipedia.org/wiki/Tidal_power (25 October 2018)

[18] Wikipedia, (2018); Ocean thermal energy conversion. (Online) Available: https:// en.wikipedia.org/wiki/Ocean_thermal_energy_ conversion (6 November 2018)

[19] Wikipedia, (2018); Wave power in India. (Online) Available: https://en.wikipedia.org/wiki/Wave_ power_in_India (5 September 2018) 